\title{
Visual Design Using Elements of Walikan Malang Language
}

\author{
Zulfikar Sa'ban ${ }^{1}$, Didit Widiatmoko Soewardikoen ${ }^{2}$ \\ ${ }^{1}$ Universitas Mercu Buana, Indonesia \\ ${ }^{2}$ Telkom University, Indonesia.
}

fiqsoda@gmail.com (Zulfikar Sa’ban),widiatmokodw@gmail.com (Didit Widiatmoko Soewardikoen)

\begin{abstract}
Malang City, in addition to having a distinctive culinary meatball. Malang is also famous for its distinctive language, the language of the walikan Malang is well-developed and still preserved by the people of Malang. The application of walikan Malang language elements on the merchandise design is growing into a popular visual culture as a medium of communication. In the further development, today the language is widely used in various media information by government, business actors, and the general public. And there are also on print media and electronic social media. The focus of the study in this research is to observe the visual design using walikan Malang language elements, which today has become a popular visual culture, especially on the product design of t-shirts that are part of a typical merchandise from Malang city. This phenomenon is interesting for the study because there are visual designs that make use of local knowledge, and there is also a process of transition of art form, from the form of language (walikan language) to another art form (visual design). In a broader sense, the term may even include the conversion of various types of science into works of art. For that, the research problem proposed in this research are: (1) How to design visual by using local knowledge (language of walikan Malang); and (2) How is the concept of developing the form/formulation of intersection between visual design meanings with verbal language (walikan language) technically.

The purpose of this research is to find out that visual design can be developed with local knowledge, in this case is walikan Malang language. The method that will be used in the study of visual design model by using walikan Malang language element is using qualitative paradigm by trying to build meaning about a phenomenon based on the views of the participants. Identifying a culture-sharing community, then examining how the community develops different patterns at one time (ethnography). By observing the behavior of the participants by being directly involved in their activities. Data in this research are library data and field data with the collection procedure through observation, interview, and documentation. The results and objectives of this study are expected to provide benefits for producers of T-shirt in SMEs (Small Medium Enterprise) to develop its visual design using walikan language, and can provide input for the city of Malang that in delivering the program/message to the public can be more optimal when using visual design with walikan language.
\end{abstract}

Keywords visual phenomenon, walikan language, form development.

\section{Introduction}

Visual design phenomenon by using elements of walikan language in the city of Malang is well-developed and still preserved by the community. The design phenomenon by using elements of Walikan language then became a popular visual culture as a visual medium in the transformation of the use of verbal language to the visual form. Language is closely related to the community in its activities. Two things are interrelated, as well as the existence of visual design phenomena by using elements of this Walikan language in Malang society. The typical language of Malang society has a characteristic that is by reversing the pronunciation of the words from behind. This phenomenon of walikan language is consistent with the opinion of linguistic scholars that language as an arbitrary system of symbolic sounds used by a group of community members to interact and identify themselves (Chaer, 1994; 3).

Currently, the visual design using walikan Malang language element has experienced a development in its use which is applied by citizens in Product Design on various media like in Merchandise. T-shirts as a part of Merchandise are widely used and become popular as a medium in using visual design with elements of walikan Malang language.

The development of visual design by using walikan Malang language element is interesting to be studied and conducted because there is a transition form of art, from language (walikan language) to another art form (merchandise). This transition also includes translation, adaptation, transfer and alteration activities. This transition is also defined as a medium used to express, attain, or exhibit ideas or feelings. In a broader sense, this term may even include the conversion of various types of science into works of art (Damono, 
2016; 13). It is also used as a bridge in parse the transition from walikan language into this visual form.

The use of walikan language is also found in other cities in Indonesia such as in Yogyakarta which is of course with its distinctive characteristics and characters, where Jogja reverses the characters ha-na-ca-ra-ka with its own reversing system. But, in its use is not similar that occurred in the city of Malang that can grow more popular and still preserved by the people until now. Visual design which incorporated walikan Malang language element today has been manifested in various visual forms on various media and creative products that can easily be found.

Previously, there are also some similar research on this walikan language, but the emphasis of the research is limited to the review and study of its language structure. While the study of visual design using the elements of walikan language, its transformation and its use in the visual form has not been much discussed in particular, it becomes necessary to make further study of visual design by using elements of walikan language that is is expressed on various media and merchandise, T-shirts are widely used and became popular as a medium in the transformation of the use of verbal language into this visual form. So, hopefully, this research can give benefit for the producer of $\mathrm{T}$-shirt in SMEs to develop its visual design by using walikan language, and can give input for Malang city government that in delivering program/message to society can be more optimal when using visual design with walikan language. And it can open the possibility of providing and adding repertoire of knowledge in the field of fine arts and product design.

\section{Theoretical Review}

There are several theories that can be used in performing visual design analysis using the walikan Malang language in addition to using the introduction theory that is Adaptation theory which has been submitted at the beginning of writing. The method of analysis used in the interpretation of verbal and visual language in this analysis one of them using the theoretical approach of denotation and connotation meaning pioneered by Roland Barthes, which at the time of reviewing the sign system not only adhered to be able to get the primary meaning/denotation but also to get it through connotation meaning. As well as with a cultural code approach by Roland Barthes, the cultural Code involves or implies the knowledge possessed by the reader (Udasmoro, 2007: 354). The reader will accept the connotation in a text, this code is a reference text to the objects that have been known or codified by the culture.

After the meaning of denotation and connotation, followed by the myths proposed by Barthes, is the second sign of the second order which is built on the principle of connotation. Relating to the dominant ideologies at the moment the sign is interpreted, so the society will take it for granted without any fight.

This theoretical approach is used to know the meanings contained in a sign in this walikan language or interpret the meaning at the time of transfer of the adaptation to the visual form so it is known how the communicators construct the message. The concept of meaning is inseparable from certain perspectives or values as well as cultural concepts that become the realm of community thinking in Malang where the process of adaptation process takes place. This approach also studies the conventions that allow these signs to have meaning (Kriyantono, 2007, 261).

A word can be a sign, as well as with other visual objects. Literary works, films, pictures, buildings or bird songs can be considered as a sign. The approach to drawing from Barthes is sufficient to see the phenomenon of visual design in current developments.

A similar approach is also used to analyze the meaning of verbal language into this visual form that is related to components in the process of creation of artwork. There are three components in the process of creating art as the foundation of work. The three components are theme, form and content. Although theoretically they can be separated but in fact these three components are an inseparable unity (Kartika, 2016; 5).

First, Themes, in a work of art, it can almost certainly that there will be the theme or subject matter, which is the core or subject matter generated as a result of the processing of objects (both natural objects and image objects) that occur in the idea of an artist with his/her personal experience; Second, Form, form is an organization or a unity or composition of elements supporting the work. There are two kinds of forms: the first is visual form, which is the physical form of a work of art or a unity of the supporting elements of the artwork. The second is special forms, the forms created by the existence of a good relationship between the values emitted by the phenomenon of its physical form to its emotional awareness response; Third, Content or Meaning, content or real meaning is the psychic form of a good believer. The believer of experience meaning of inner life will be aware of the variety of possible aesthetic forms, which can accommodate and spur the creation of various meanings and values.

This theoretical approach is used to help in sorting out the object of study (brand T-shirts) which are quite diverse in the community, based on the three components, namely based on the theme, form and content contained in the object of the shirt. Some of the themes that are quite often used as design themes in this Walikan language t-shirt are: (a) the theme of the activities of the Arema football club supporters; (b) the theme of Malang culinary; (c) the theme of transportation; (d) identity of Malang City; (e) the theme of tourist attractions; and (f) the language of everyday social expression.

\section{Method}

The method that will be used in the study of visual desi gn model by using walikan Malang language element is using qualitative paradigm by trying to build meaning ab out a phenomenon based on the views of the participants. Identifying a culture-sharing community, then examining how the community develops different patterns at one ti me (ethnography). By observing the behavior of the parti cipants by being directly involved in their activities (Cre 
swell, 2017, 24-25). In understanding human behavior, th e researcher uses steps in ethnographic methods that offe $r$ one way to discuss the reality of meaning, according to the ethnographic goal is to understand the human family (Spradley, 1997; 16). Using the theory of adaptation the ory as an introduction to the subject of transformation/ad aptation of verbal to visual. Using the approach of visual data analysis, the stages of describing and interpreting $i$ mages. Visual analysis required the process of observatio $\mathrm{n}$, which is different from the process of viewing the usu al (Soewardikoen, 2013; 39). Using the theory of Roland Barthes to discuss the signification meaning, as well as using the approach of artistic creations, to discuss the co ncept of art creation.

\section{Result and Discussion}

In this section, the researchers will discuss about how the existence of object research in the form of visual design that is designed by using local knowledge (walikan Malang language). From the observations made by the researchers to the field, we encounter many object studies in the form of visual design that uses elements of this walikan language are currently widely used by various elements of society. To facilitate the explanation, the researchers have created categories of object based on the study found in the field as follows:

a) Visual design that uses elements of walikan language, used/made by the general public.

b) Visual design that uses elements of walikan language, used/made in electronic social media.

c) Visual design that uses elements of walikan language, used/made by the company as a media campaign.

d) Visual design that uses elements of walikan language, used/made by Malang city government agencies.

e) Visual design that uses the elements of walikan language, used/made by the producer of t-shirts in SMEs

Some visual design which incorporated visual elements on the t-shirts will be taken as examples of the discussion in this study. As the researchers found from the results of field observations, there are many independent creative business or SMEs (which are mainly producers of t-shirts in the city of
Malang), especially those who incorporated many elements of walikan Malang language. Then, the selection of the study object is based on the criteria determined by the researchers, which is the producers of t-shirt who have official outlets/workshops. This selection aims to help the researcher to find the valid data and maintain the consistency. Then, the researchers also determine the producers of shirts that have official outlets/workshops as follows:

(1) Soak Ngalam;

(2) Osob Kiwalan;

(3) Oyi Sam;

(4) Soak Ayas;

(5) Arema Fashion;

(6) Walikan.

Here are the t-shirts manufacturer's logo:

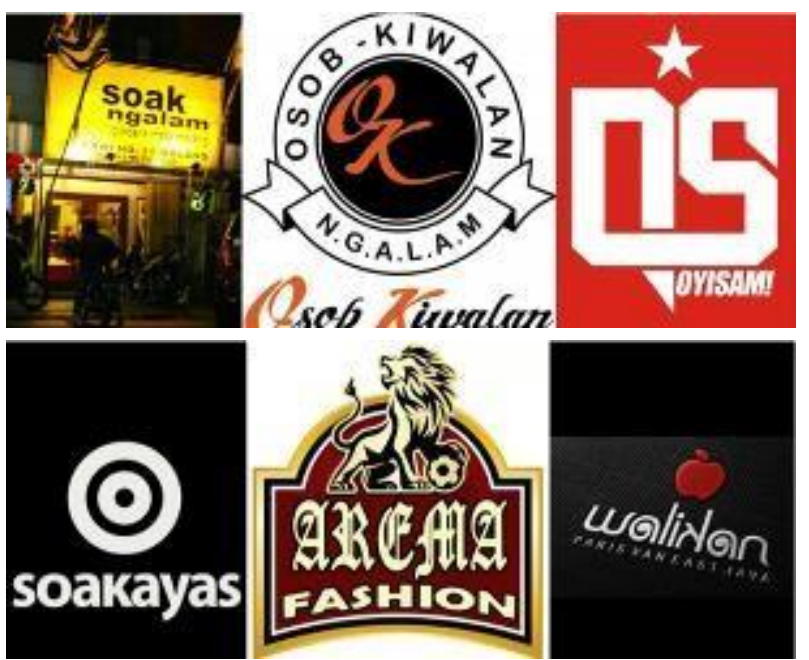

The themes used by the producers of t-shirts are mostly about the activities of football club supporters of Arema, about culinary in Malang, about transportation, about the sights, regarding the language of everyday social expression, and about the identity of Malang. Here is described further as an example, one of the products of SMEs, the producer of Osob Kiwalan T-shirts that uses the theme of identity in Malang City.

Example of the t-shirt design and explanation 


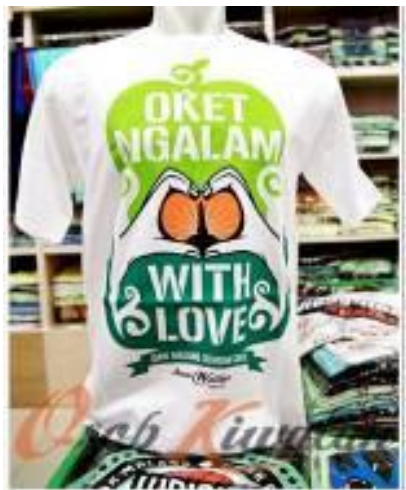

Figure 1. Source: osobkiwalan.com

- Transformation of walikan language to visual form There is a saying: "oket ngalam with lovee or in reverse "teko malang with love" which means from Malang with Love.

\section{- Denotation Sign}

There is a light green background on the top and dark green bottom of the composition of the image that forms the silhouette of an apple. There are also some decorative accents on the side of the background such as Javanese tendrils or similar to a branch of a tree. At the center of the picture there are some illustration, consisting of Malang Monument image of black and orange colored with ray effect from the back, and framed by two hands with the position of closing the fingers of both hands to resemble the shape of the heart.

\section{- Connotation Meaning}

In the composition of the picture, there is a form of apple-like background that is meant that the city of Malang is identical with apple fruit. In the middle, there is an icon of the city of Malang, which is the monument that located right in front of Malang City Hall. And two hands that approach and form the heart is the embodiment of the word "with love" at the bottom of the hand drawing.

- Myth, which refers to culture:

The people of Malang City are always open for anyone who come to visit this city. No need to worry about Malang because it is not similar to Jakarta which is sometimes always represented as harsher than one's stepmother. Life in Malang is relaxed; therefore, the people are also relaxed. Hospitality of Malang people cannot be denied. Just do not expect courtesy, gentle and Javanese speech such as Kromo Inggil (which are mostly used by people of) Jogja and Solo, but that does not mean they are not polite. The way Malang people talk sometimes more similar to a person who speaks out everything frankly and often use a high tone. But they do so not because they are being angry, that is actually the form of Malang-style hospitality, which is sweet in its own way.

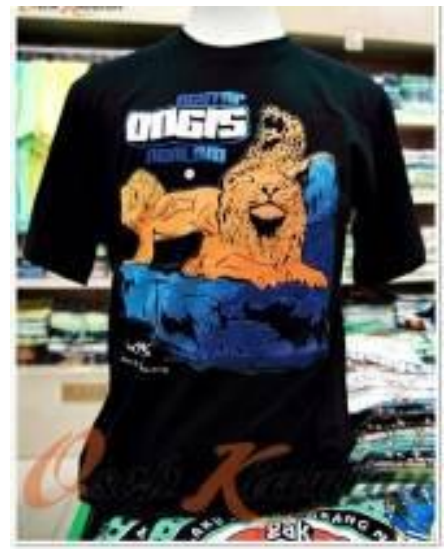

- Figure 2. Source: osobkiwalan.com

- Transformation of walikan Malang language to visual form

There is a saying which is "ngutap ongis ngalam" or "patung singo Malang" which means a lion statue in Malang.

- Denotation Sign

There is writing, "ngutap ongis ngalam" which uses solid sturdy typography. The words "ngutap" and "ngalam" are smaller and use a blue color, while the words "ongis" larger and using white color. The main object of the illustration draws a resemblance of a three-tailed lion animal with various positions using a golden yellow color. And it stands on a place or rocks that use blue color.

- Connotation Meaning

The writing "ngutap ongis ngalam" which means the lion statue of Malang explains that the object in the t-shirt design is a statue which is in Malang City. The lion statue shows that Malang city is identical with this lion logo. While the golden yellow color resembles the original color of this animal skin, while the blue color of the rock is representing the color of greatness or uniform color of the Arema Malang team.

- Myth, which refers to culture

The symbol of the city of Malang, first used and established in 1937, is a blue shield, with a red yellow gold crown underneath, and being carried by two lions standing on two legs, and yellow gold with its tongue protruding. Inside the shield which is held by the lions, there is still a lion that has a yellow gold color. And behind it, there is a white lotus with a 
long stalk, and a valley of plantations. At the bottom of the lion is a blue ribbon that is gripped by both lions and there is a slogan that reads: "Malang Nominor Sursum Moveor" which means "Malang Is My Name, Moving Forward is My Goal" (Widodo, 2015, 485). So, it can be understood that the city of Malang is identical with a lion and the color of its greatness is blue, which is finally used by the team of Arema Malang with lion as its logo and blue as the color of their uniform, up to now.

\section{Conclusion}

Visual design which incorporated elements of walikan Malang language is growing quite well in the form of visual (merchandise), especially on the media of t-shirts. The process of adaptation technically can be observed through the fact the many things can be used as the theme of t-shirt design as in the previous discussion. Although there is still a possibility, there are other themes that will continue to be developed by the designer of t-shirts walikan Malang in the future. The category based on the theme used is very important because in Malang today there are many merchandise products, especially t-shirts that use Walikan language as its design theme.

The themes in general and from the technical side can be transferred and adapted into the visual form because when viewed from the signs of denotation in general the shirt designs use or utilize forms, illustrations drawings and typography that is close enough or quite popular with the people of Malang as for example: picture of Arema team supporter, form of apple, drawing of a meatball, coffee, icon of crazy lion (singo edan), which is already very identical with the society of Malang city. But, there is still a gap when the adaptation of these works when they are being interpreted in connotation meaning, some gaps that appear for example about the color that is less in accordance with the intent, illustration of images that are technically less clear, the color combination of the basic colors of t-shirts with the colors contained in the image design, as well as the selection of types of typography combined with graphic accents as well as a combination of size typography with the field of $\mathrm{t}$-shirts and proportion with the overall image design. Gap in technical terms is quite disturbing when the design will be interpreted as a whole connotation.

From the finding, it is expected to provide an overview in knowing the visual design which incorporated a local knowledge walikan Malang language), and understanding the concept of development of form/formulation of intersection between the meaning of visual design with verbal language (walikan language) technically.

\section{ACKNOWLEDGEMENT(S)}

The researchers would express appreciation and thanks as much as possible on many parties which helps this research, there are: Author of book of 100 years of Malang, Owner of Malang Malang Tempo Doeloe, Illustrator/comic artist/designer who incorporated the walikan language, Owner/Manager of T-shirts manufacturer, Promotion/Public Relations Division which use visual design with Walikan language, and Malang City Government (including the department of landscaping and urban planning department, and tourism office).

\section{REFERENCES}

Barthes, R. 1972. "Membedah Mitos-mitos Budaya Massa". Jakarta: Jalasutra, 299-300.

[2] Chaer, A. 1994. “Linguistik Umum”. Jakarta: Rineka Cipta, 3.

[3] Creswell, J. W. (2017). "Research Design, Pendekatan Metode Kualitatif, Kuantitatif dan Campuran”. Yogyakarta: Pustaka Pelajar.

[4] Culler, J. 2002. "Barthes, Seri Pengantar Singkat (Terjemahan Ruslani)". Yogyakarta: Jendela, 52.

[5] Damono, S. D. 2016. “Alih Wahana”. Jakarta: Editum, 13.

[6] Kartika, D. S. 2016. "Kreasi Artistik, Perjumpaan Tradisi Modern dalam Paradigma Kekaryaan Seni”. Karanganyar: Citra Sains, 5.

[7] Dinas Kebudayaan dan Pariwisata Kota Malang. "100 Tahun Kota Malang, Menelusuri Kilasan Sejarah Kota Malang”. 2014. Malang: Dinas Kebudayaan dan Pariwisata Kota Malang.

[8] Kurniawan. 2001. "Semiologi Roland Barthes". Magelang: Indonesiatera. 
[9] Kriyantono, Rachmat. 2007. "Teknik Praktis Riset Komunikasi”. Jakarta: Kencana, 261-268.

[10] Miles \& Huberman. 1992. "Analisis Data Kualitatif (tentang metode-metode baru)". Jakarta: UI-Press, 16-20.

[11] Soewardikoen, D. W. 2013. "Metode Penelitian Visual". Bandung: Dinamika Komunika, 39.

[12] Spradley J. P. $1997 . \quad$ "Metode Etnografi (terjemahan)". Yogyakarta: PT. Tiara Wacana, 16.

[13] Udasmoro, W. (2007). "Petualangan Semiologi Roland Barthes”. Yogyakarta: Pustaka Pelajar, 354.

[14] Widodo, Dukut Imam. 2015. "Malang Tempo Doeloe”. Surabaya: Dukut Publishing, 485. 